\title{
Factors Affecting Parental Choice of Private and Public Schools in Dhading
}

\author{
Yuba Raj Subedi \\ Nilkantha Multiple Campus, Dhading
}

\begin{abstract}
This study explores the factors which attract parents to prefer public or private schools. The data were collected from six secondary schools of Dhading district. From each school, three parents were selected by using non-random sampling method. The eighteen parents were given a questionnaire. The collected questionnaire was analyzed and interpreted descriptively. A comparison of results was undertaken to explore the identified factors related to the Quality of Instruction; Class Size; Teacher-Student Relationship; Parent-School Relationship; School Facilities and Environment for learning. It was found that Class Size was the strongest factor that parents had a higher agreement on this variable. The second strong factor was favorable environment for their children and the final influencing factor of parental choice was identified as School Facilities.
\end{abstract}

Keywords: favorable environment, parental choice, private and public schools, school facilities

\section{INTRODUCTION}

There are various types of opinions on disparities between private and public schools in Nepal that create a debate on whether school education should privatize or not. There are opinions for and against privatisation in school education. Some people argue that privatisation in school education should not be promoted because it creates two classes of citizens. Similarly, some people argue that school education is entirely responsible for the government. On the other hand, some give logic that the government has failed to offer quality education for all children due to a shortage of funds. Therefore, this study explored the factors that affect parental choice in public and private schools in Dhading.

The issues of profit-making rather than service-oriented are hot cake in the private school. It is a political hot topic in Nepal (Caddell, 2007). Pokharel (2008) mentioned that the Private education system is openly criticised for making the education sector a business platform, lacks accountability to the public society. Private schools were not profit-making ventures as they are today before the national education system plan (Chitrakar, 2007). After then some founders gradually promoted the idea of gaining benefits from private schools (Khaniya and Williams, 2004). Kiteav (1999) claimed that one of the major motivations for founding private schools is the possibility of making a profit. Although Education Act and Regulation has laid provisions for better managing and regulating private schools, the government is not able to strictly implement the legal provisions (Bhattarai, $2063 \mathrm{BS}$ ). That's why; there is always conflict in the issue of exorbitant fee structure at the beginning of the session or at the time fee 
increments in Nepal (Chitrakar, 2007). The main logic behind private schools is the delivery of quality education (Chitrakar, 2007).

Mathema (2007) argues that the problem of low quality of education in public schools is compounded by the surge in the number of expensive profit-making schools, which cater to the children of richer parents. He stressed that the dual system of school education must be ended because it offers quality education to few and denies to great majority. Poor public schools invite privatization in education and privatization ruins the public schools. In the world, there is a high demand for private schooling and rapid growth in the number of private schools where public schools' performance is poor.

The challenge of educating children does not end with enrollment; it involves providing children with good schooling. It is the right and obligation of parents to look for better education. All private schools are not expensive; there are low-fee private schools too. The low-fee private schools are assisting to provide access and quality education to poor households (Tooley, 2001).

Since the beginning of the 21st century, the demand for private schools in Nepal has increased very quickly because the government has supported them to reduce the burden on the public school sector, as well as to provide modern teaching techniques and up-to-date global content in the educational field. (Aldoasri, 2009). Furthermore, the government has granted private schools considerable margins of freedom in several aspects of education, such as the selection of teachers and students, pupils' activities, offering extra-curricular activities, stimulating classrooms and small class sizes. In recent years, therefore, there has been a rapid increase in the number of pupils who have been enrolled in private schools.

Although, there has been an increase in the number of pupils who enroll in private schools each year, some research studies, such as Alansuer (2004) and Aljije (2002), have found that parents with children enrolled in private schools are not always satisfied with the performance of their children, despite the high fees they spend on their education. When pupil performance has been very disappointing and does not meet parental expectations, this may result in disaffection among parents about the quality and condition of education. These concerns about quality are exacerbated since, although the Nepal government spends millions on education, student outcomes remain disappointing because education does not prepare students for the jobs marketplace and modern life. These factors have led to parents removing their children from private schools and sending them to a public school that better meets their expectations. Vice versa, parents also remove their children from public schools and send them to a private school that better meets their expectations. Thus, this study has explored the strengths and weaknesses of both private and public school education systems, particularly from the perspective of parents, together with which attributes they consider to be essential for their children to fulfill their full potential. The researcher is very keen to undertake this study and take up this challenge to investigate specific issues from the perspective of parents who have sent their children to private or public schools in Dhading Bensi. 
Thirty reasons behind parental school choice that Coldron and Boulton (1991) identified are grouped below in four main categories: academic/educational, safe school, organization, source (sibling of student). Similarly, Taylor (1996) provided a list of four main categories that attract parents to choose a particular school: academic factors (Quality of curriculum, quality of instruction, commitment of teachers, high achievement), convenience factors, proximity of the school, religious/moral factors. In the same way, according to Charles (2011), however, five main categories attract parents to choose a school: quality of the instruction, support for students' learning, school climate/environment for learning, parent/school relationship, and resource management. While for Yi Hsu and Yuan-Fang (2013) there are six main categories: educational environment, educational philosophy, school and facilities, curricular activities, school specialties, location and transportation.

In the United Kingdom, Wood et al. (1998) conducted a study on 1000 parents to determine the factors that influenced them to send their children to secondary schools located in three areas Marshampton rural area, East Greenvale-a semi-rural area and Northern Heights-an urban area in northern England. Parents were asked to rank factors such as the headteacher, the school staff, pupils' behavior in the school, the school atmosphere, uniform, facilities (rooms, equipment, books, etc.), the class sizes, the standard of academic education, whether the school is a single-sex school, exam results, discipline policy, the school's reputation, whether the child's friends will be there, the school's attitude to parents, its closeness to home/convenience for travel, whether the child has special educational needs, whether it is the child's preferred school and the child's happiness at the school. The results of the study differed between the case areas. In one of the urban schools, parents were influenced by whether the child's friend would be at the school and the school's nearness to home/convenience for travel. In another school, however, parents were influenced by the standard of academic education and exam results. In the third school, academic factors were also important, with the school's reputation and the standard of academic education being ranked most highly.

In Holland, Denessen et al. (2005) investigated the reasons for school choice by collecting data from more than 10,000 parents of students attending 700 Dutch private schools. The parents were asked to rate 17 reasons for choosing their school, for instance, "school environment, the social background of most of the pupils, no other school available, order and discipline, the reputation of the school, pupils attending this school get ahead in society, the school pays attention to each child, other parents are our kind of people, extra-curricular activities, denomination of the school, school is within easy reach, the possibility of coming into contact with other cultures, quality of education, attractive school building, advice of friends, class size and school is considerate of our religion." (p.34). In this study, quality of education was the most important reason that attracted parents to select a school, with other reasons for school choice related to academic quality, environment, order, and discipline.

Alansari (2004) carried out a study in Dammam City to explore the reasons that encourage parents to send their children to private schools. He found the most important reason 
to be the high qualifications of teachers, who (a) educated the students using advanced technology, (b) could understand the problems of students and help them to overcome the challenges, and (c) used modern theories to develop social values.

This study uses factor analysis to combine the main categories of factors listed above into eight primary factors to explore the most important influences on parents' school choice decisions. The academic factor is divided into four variables: academic programme; the qualifications of teachers; the relationship between students and teacher; the class size. The second factor is the school/parent relationship. The third factor: the convenience factor (suitability) was divided into four variables: the school facilities; physical education and sport; social status determinants; the safe educational environment. The purpose of this study, therefore, is to explore a variety of factors related to parental perceptions of the differences between private and public schools in Dhading.

\section{METHODOLOGY}

A descriptive approach to research had been taken to describe the parents' perception of public and private schools in Dhading Bensi. A survey design was judged to be the most appropriate for the present study for several reasons. According to Wisker (2007) and Gilbert (2008), a survey study allows researchers to obtain information about the case, facts, activities, phenomena, morals, personal experiences, behavior, and answers to events. In other words, it describes the qualities, opinions, or perspectives of a population by the use of a targeted sample. Moreover, the researcher will be able to obtain data about the sample using several approaches, such as face-to-face interviews, and hand-delivered questionnaires. Cohen et al (2011:421) confirm that obtaining data typically involves "structured or semi-structured interviews, selfcompletion or postal questionnaires, standardized tests of attainment or performance, and attitude scales". Finally, using a survey study is commonly used in educational studies to describe what exists without asking about the reasons: Cohen et al (2011:256), "the most commonly used descriptive method in educational research". In this study, a questionnaire was used to collect the data.

The researcher selected 18 parents from 3 private schools (Childrenpark Boarding School, Dhading Boarding School and Advance Academy) and 3 public schools (Neelakantha Secondary School, Balmandir SecondarySchool and Pashupati Secondary School) of Dhading Bensi as the population for this study. The researcher selected 3 private schools and 3 public schools of Dhading Bensi. He built rapport with the principals of selected schools and selected 9 parents from 3 private schools and 9 from 3 public schools through judgmental sampling under a non-random sampling procedure.

The questionnaire was used as the tool for collecting the required information. Closedended questions were used to elicit information from the parents. The systematically collected data was analyzed, interpreted and presented descriptively. Simple statistical tools such as a measure of frequency and percentage were used to analyze and interpret data. 


\section{RESULTS AND DISCUSSION}

The importance of school choice lies not only in the development of the quality of education through competition among schools, but may also be extended to motivate parents to engage in their roles in the educational process as actors in educational policy-making. Some educationalists contend that the participation of parents in the educational process can act as a mechanism for educational reform. School choice, therefore, encourages parents to take more interest in the education process. School is not something that just happens but is something they have taken a conscious decision about, which is both empowering and gives the confidence to continue to get involved. Additionally, students interact with similar-minded peers in terms of dimensions of culture and values, which mean the parents, can promote their community's attitude within the education process through the school choice system.

Parents, when making decisions about both types of school (public and private), cited their academic quality as an important reason for their choice. Parents who enroll their children in private schools believe that they are of better academic quality than public schools.

Teachers play a critical role in the success of the school as they can develop strategies that address the educational needs of every student and implement varied learning styles to convey the knowledge from the textbook to students successfully. Adeogun (2001) argued that the quality of the education system is dependent on the quality of its teachers and that a school with inadequate human resources may not be able to meet the objectives of the education system. Other scholars, exploring the role of teachers in more detail, argue that there are many ways in which teachers' attitudes, behaviour and qualities can have a positive impact on student outcomes and school choice. For instance, Vanderbrook (2006) states that teachers must be motivated to teach very able students, employing creative and student-centered methods, without prejudice against either girls or boys or ethnic minorities. Teachers impact all aspects of the education process. Thus, it is important to investigate the performance of teachers in schools because they represent one of the most important reasons that may attract parents to value the school. It can be seen that teachers' qualifications; their knowledge of their academic subject; how they impart information to their children preferably using modern technologies, along with interesting, stimulating problem-solving methodologies are important to parents, and therefore influences their school choice. Equally, it is important to parents that the chosen school and its teachers have a sound reputation for addressing individual children's needs, build their selfconfidence and self-esteem, and ensure pupils' safety. Parents consider teachers to have a very considerable lifelong effect on pupils' personal and academic achievements. It is very important to parents who value teachers, therefore, that they use varied teaching methods, care for their children's well-being, help their children to overcome the challenges that face them in education by nurturing the whole child, i.e. his/her intellectual potential, respect for others, behaviour, physical development, self-awareness, encouraging good citizenship. This leads to the importance of teacher-children relationships. The relationship between students and teachers is very important in assisting students to overcome the educational challenges that they may face in 
their school lives, e.g. stress, self-esteem, difficulty in understanding some topics in a variety of lessons. Lee (2007) concluded that a positive relationship between teachers and students will motivate students' exploration and enthusiasm for knowledge, and thereby improves their educational attainment. He adds, therefore, "A trust relationship has been found to function as a motivational resource when students are faced with difficulties in school because trust relationships help adolescents develop positive psychological and emotional perceptions of them." In conclusion, the beneficial aspects embedded in solid teacher-student relationships are fundamental to school choice, especially when they nurture self-esteem, positive behavioural outcomes, and self-confidence and uphold the existing family standards of behaviour, making the school very attractive to parents.

The central point is that with reduced class size, students are given opportunities to practise interpersonal skills and to see themselves as significant individuals, with a sense of personal power, whose actions and opinions have ensured that each student perceives that he is known by important adults who care for him, thereby enhancing self-esteem. Having smaller classes is advantageous in many ways to both teachers and students because it makes the teaching/learning atmosphere more interesting and enjoyable; teachers have more time to become familiar with their student's abilities, interests and problems. This is indicative that small class size tends to positively impact the examination results of students. Small class size allows the teacher to support and help students individually by having the time and opportunity to answer each question or offer suggestions, while students are more involved in problem-solving activities. It is concluded that class size is a very important element in parental considerations when deciding which private or public school to choose. Parental decisions are based on the assumption that a smaller class equates to a more suitable quality learning environment in which the student's achievements and development will be enhanced through a constructive relationship between teachers and learners in which teachers have more time to devote to supporting each individual learner. Outstanding schools emphasize communication between parents and school as very important, parents as part of the success of the educational process. Thus, schools should plan to reduce the gap between the school and parents by making parents feel welcome, improving the relationship of trust between school and teachers and opening a discussion regarding morals and faiths. Collaboration between school and parents is necessary to achieve the school's educational objectives and to increase the awareness of parents of their role in educating children.

\section{Academic Programme}

In the first of the factor analyses, 14 items relating to 'academic' matters were entered into the analysis. This produced mainly 3 factors, 'quality of the instruction', 'relationship between the teachers and the students' and 'class size'. 
Table 1: Academic factors

\begin{tabular}{|c|c|c|c|c|c|c|}
\hline \multirow[b]{2}{*}{ No } & \multirow[t]{2}{*}{ Factors } & \multicolumn{5}{|c|}{ Total Percentage } \\
\hline & & $\begin{array}{c}\text { Strongly } \\
\text { Agree }\end{array}$ & Agree & Disagree & $\begin{array}{l}\text { Strongly } \\
\text { Disagree }\end{array}$ & $\begin{array}{l}\text { Don't } \\
\text { know }\end{array}$ \\
\hline 1. & $\begin{array}{l}\text { Teachers use a variety of teaching } \\
\text { strategies and learning activities to } \\
\text { help students learn. }\end{array}$ & $33.33 \%$ & $61.11 \%$ & $5.55 \%$ & & \\
\hline 2. & $\begin{array}{l}\text { The education offered to students at } \\
\text { our school is of high quality. }\end{array}$ & $33.33 \%$ & $61.11 \%$ & $5.55 \%$ & & \\
\hline 3. & $\begin{array}{l}\text { The school is teaching all subjects } \\
\text { well. }\end{array}$ & $61.11 \%$ & $27.77 \%$ & $11.11 \%$ & & \\
\hline 4. & $\begin{array}{l}\text { The teaching strategies used at this } \\
\text { school are innovative. }\end{array}$ & $22.22 \%$ & $72.22 \%$ & $5.55 \%$ & & \\
\hline 5. & $\begin{array}{l}\text { Teachers are efficient (well } \\
\text { prepared and highly qualified) }\end{array}$ & $38.88 \%$ & $61.11 \%$ & $5.55 \%$ & & \\
\hline 6. & $\begin{array}{l}\text { The school is preparing students to } \\
\text { deal with issues and the problems } \\
\text { they will face in the future. }\end{array}$ & $33.33 \%$ & $55.56 \%$ & $11.11 \%$ & & \\
\hline 7. & $\begin{array}{l}\text { Teachers conduct communicative } \\
\text { activities like pair work, group } \\
\text { work, role play, etc in class }\end{array}$ & $38.88 \%$ & $55.56 \%$ & $5.55 \%$ & & \\
\hline 8. & $\begin{array}{l}\text { Teachers use advanced technology } \\
\text { to deliver knowledge to students, } \\
\text { such as computers, smart boards, } \\
\text { projectors. }\end{array}$ & $27.77 \%$ & $66.66 \%$ & $5.55 \%$ & & \\
\hline 9. & $\begin{array}{l}\text { The relationship between the } \\
\text { teachers and students is very good }\end{array}$ & $61.11 \%$ & $33.33 \%$ & $5.55 \%$ & & \\
\hline 10. & $\begin{array}{l}\text { Teachers at our school treated my } \\
\text { child fairly }\end{array}$ & $38.88 \%$ & $44.44 \%$ & $16.66 \%$ & & \\
\hline 11. & $\begin{array}{l}\text { Teachers are friendly and sincere } \\
\text { with students. }\end{array}$ & $61.11 \%$ & $33.33 \%$ & $5.55 \%$ & & \\
\hline 12. & $\begin{array}{l}\text { Class size at our school is } \\
\text { appropriate for effective learning }\end{array}$ & $16.66 \%$ & $55.56 \%$ & $27.77 \%$ & & \\
\hline 13. & $\begin{array}{l}\text { The children have been enabled to } \\
\text { learn the English language }\end{array}$ & $16.66 \%$ & $72.22 \%$ & $11.11 \%$ & & \\
\hline 14. & $\begin{array}{l}\text { The reputation of the school is } \\
\text { excellent and it also provides extra- } \\
\text { curricular activities. }\end{array}$ & $44.44 \%$ & $55.56 \%$ & & & \\
\hline
\end{tabular}


In conclusion, the three dimensions: quality of the instruction, class size and teacherstudent relationships, have been identified as the most important academic-related factors in respect to school choice. This is because parents give high priority, even to the extent of either considering or sending their children to a more distant school, to be assured that their children would be taught by qualified committed teachers. More specifically, overall parental perceptions of the preferred public school in terms of the Academic Factor aspect included:

- The school is teaching all subjects well.

- The education offered to students at our school is of high quality.

- Teachers are friendly and sincere with students.

- Teachers at our school treated my child fairly

The most important factors that had an impact upon parents' choice of private school, however, were:

- The school is teaching all subjects well.

- Class size at our school is appropriate for effective learning.

- Teachers at our school treated my child fairly

- Teachers are friendly and sincere with students.

\section{Relationship between Parents and School}

In the second factor analysis, six items relating to the relationship between parents and school were analysed. The related factors are shown below in table 2 .

Table 2: Relationship between Parents and School

\begin{tabular}{|c|l|l|l|l|l|l|}
\hline & \multicolumn{2}{|c|}{ Factors } & \multicolumn{3}{c|}{ Total Percentage } \\
\hline $\mathbf{1 5 .}$ & $\begin{array}{c}\text { Strongly } \\
\text { Agree }\end{array}$ & Agree & Disagree & $\begin{array}{l}\text { Strongly } \\
\text { Disagree }\end{array}$ & $\begin{array}{l}\text { Don't } \\
\text { know }\end{array}$ \\
\hline $\mathbf{1 6 .}$ & $\begin{array}{l}\text { The school provides sufficient } \\
\text { opportunities for parents involved } \\
\text { in the school development }\end{array}$ & $34.44 \%$ & $33.33 \%$ & $22.22 \%$ & & \\
\hline $\mathbf{1 7 .}$ & $\begin{array}{l}\text { Parents are invited to the school } \\
\text { frequently. }\end{array}$ & $44.44 \%$ & $50 \%$ & $5.55 \%$ & & \\
\hline $\mathbf{1 8 .}$ & $\begin{array}{l}\text { Parents co-operate with the } \\
\text { school administration. }\end{array}$ & $27.77 \%$ & $66.66 \%$ & $5.55 \%$ & & \\
\hline $\mathbf{1 9 .}$ & $\begin{array}{l}\text { The school uses technology to } \\
\text { provide parents with information } \\
\text { about the progress of students at } \\
\text { the school }\end{array}$ & $33.33 \%$ & $55.56 \%$ & $11.11 \%$ & & \\
\hline $\mathbf{2 0 .}$ & $\begin{array}{l}\text { Parents' opinions are considered } \\
\text { when important decisions are } \\
\text { made }\end{array}$ & $22.22 \%$ & $50 \%$ & $27.77 \%$ & & \\
\hline
\end{tabular}


Table 2 shows that there are six items loaded on the fourth factor: 'The relationship between school and parents. This factor included six items: 'parents' opinions are considered when important decisions are made' received a factor loading of $72.22 \%$; 'the school provides sufficient opportunities for parents' involvement in the school development' received a factor loading of $72.21 \%$; 'parents accept voluntary membership in school committees and organized assignments' received a factor loading of $77.77 \%$; 'parents co-operate with the school administration' received a factor loading of $94.43 \%$ which is the second-highest factor of parents' choice; 'the school uses technology to provide parents with information about the progress of students at the school' was $88.89 \%$ that is the third highest factor; and 'the parents are invited to the school frequently' received $94.44 \%$ whithird-highestst highest factor of parents' choice. The above were measures of the perception of parents related to the importance of the relationship between parents and the school.

\section{School Facilities}

The third-factor analysis dealt with items relating to school facilities, 7 items were entered and this produced 2 main factors, 'educational facilities' and 'and sports activities. This is shown in table 3:

Table 3: School facilities

\begin{tabular}{|c|c|c|c|c|c|c|}
\hline \multirow[b]{2}{*}{ No. } & & \multicolumn{5}{|c|}{ Total Percentage } \\
\hline & & $\begin{array}{l}\text { Strongly } \\
\text { Agree }\end{array}$ & Agree & $\begin{array}{c}\text { Disagre } \\
\mathrm{e}\end{array}$ & $\begin{array}{l}\text { Strongly } \\
\text { Disagree }\end{array}$ & $\begin{array}{l}\text { Don't } \\
\text { Know }\end{array}$ \\
\hline 21. & $\begin{array}{l}\text { The classrooms have a good } \\
\text { environment (enough lights, fans, } \\
\text { comfortable tables and nice carpet) }\end{array}$ & $5.55 \%$ & $77.77 \%$ & $16.66 \%$ & & \\
\hline 22. & $\begin{array}{l}\text { The school has good computer and } \\
\text { internet services }\end{array}$ & $16.66 \%$ & $66.66 \%$ & $16.66 \%$ & & \\
\hline 23. & The school has good library services. & $44.44 \%$ & $55.56 \%$ & & & \\
\hline 24. & $\begin{array}{l}\text { The school has good laboratories for } \\
\text { computers and science. }\end{array}$ & $11.11 \%$ & $77.77 \%$ & $11.11 \%$ & & \\
\hline 25. & $\begin{array}{l}\text { The school has good indoor games } \\
\text { facilities. }\end{array}$ & $5.55 \%$ & $55.56 \%$ & $38.88 \%$ & & \\
\hline 26. & $\begin{array}{l}\text { The school has outdoor game } \\
\text { facilities }\end{array}$ & $16.66 \%$ & $50 \%$ & $33.33 \%$ & & \\
\hline 27. & The school has a good playground & $16,66 \%$ & $50 \%$ & $33.33 \%$ & & \\
\hline
\end{tabular}

In summary, the most important school facilities related factors that influenced parents to choose a public school are:

- The school has good library services.

- The school has computer and internet services.

- The school has good laboratories for computers and sciences. 
While the most important educational facilities factors that influenced parents to choose a private school are:

- The school has computer and internet services.

- The classrooms have a good environment (enough lights, fans, comfortable tables and nice carpet).

- The school has good laboratories for computers and sciences.

- The school has good indoor and outdoor games.

- The school has a good playground.

\section{Environment for Learning}

In the fourth and final factor analysis, the last 7 items were entered. The factor analysis of these produced mainly 2 factors, 'favorable environment' and 'school rules'. These factors are shown in table 4 below:

Table 4: Environment for learning

\begin{tabular}{|c|l|l|l|l|l|l|}
\hline \multirow{2}{*}{ No. Factors } & \multicolumn{1}{|c|}{} & \multicolumn{4}{c|}{ Total percentage } \\
\cline { 3 - 7 } & & $\begin{array}{c}\text { Strongly } \\
\text { Agree }\end{array}$ & Agree & Disagree & $\begin{array}{c}\text { Strongly } \\
\text { Disagree }\end{array}$ & $\begin{array}{l}\text { Don't } \\
\text { Know }\end{array}$ \\
\hline 28. & $\begin{array}{l}\text { School rules apply equally to all } \\
\text { students. }\end{array}$ & $55.56 \%$ & $44.44 \%$ & & & \\
\hline 29. & $\begin{array}{l}\text { The school provides a safe and } \\
\text { favorable environment for } \\
\text { learning. }\end{array}$ & 33.33 & 61.11 & 5.55 & & \\
\hline 30. & $\begin{array}{l}\text { School has good rules and } \\
\text { regulations for morality and } \\
\text { applied behavior management of } \\
\text { students }\end{array}$ & 33.33 & 61.11 & 5.55 & & \\
\hline 31. & $\begin{array}{l}\text { Cheating is strongly discouraged } \\
\text { at the school }\end{array}$ & $50 \%$ & $50 \%$ & & & \\
\hline 32. & $\begin{array}{l}\text { The school provides safe } \\
\text { transportation for the students }\end{array}$ & $11.11 \%$ & $77.77 \%$ & $11.11 \%$ & & \\
\hline 33. & $\begin{array}{l}\text { There is not any physical } \\
\text { punishment at school }\end{array}$ & $5.55 \%$ & $77.77 \%$ & $16.66 \%$ & & \\
\hline 34. & $\begin{array}{l}\text { There is a peaceful environment } \\
\text { with good facilities at school. }\end{array}$ & 33.33 & $50 \%$ & $16.66 \%$ & & \\
\hline
\end{tabular}

Table 4 shows that there were seven items loaded on the seventh factor: 'Favorable Environment'. The factors 'school rules apply equally to all students' and 'cheating is strongly discouraged at the school' received $100 \%$ positive responses from parents. In the same way, the factors 'the school provides a safe and favorable environment for learning' and 'school has good rules and regulations for morality and applied behavior management of students' received 
94.44\% positive responses. The factors 'the school provides safe transportation for the students' received $88.88 \%$; 'there is not any physical punishment at school' received $83.32 \%$ and 'there is a peaceful environment with good facilities at school' received $83.33 \%$.

The important favorable environment factors identified as affecting parents in their preferred public school choice were, therefore:

- The school rules apply equally to all students.

- The school provides a safe and favorable environment for learning.

- There is a peaceful environment with good facilities at school.

While the most important favorable environment-related factors that influenced the parental choice of a private school were:

- The school provides a safe and favorable environment for learning.

- Cheating is strongly discouraged at school.

- There is not any physical punishment at the school.

- There is a peaceful environment with good facilities.

\section{Importance of School Choice}

The importance of school choice lies not only in the development of the quality of education through competition among schools, but may also be extended to motivate parents to engage in their roles in the educational process as actors in educational policy-making. Some educationalists contend that the participation of parents in the educational process can act as a mechanism for educational reform. School choice, therefore, encourages parents to take more interest in the education process. School is not something that just happens but is something they have taken a conscious decision about, which is both empowering and gives the confidence to continue to get involved. Additionally, students interact with similar-minded peers in terms of dimensions of culture and values, which means the parents, can promote their community's attitude within the education process through the school choice system.

Parents, when making decisions about both types of school (public and private), cited their academic quality as an important reason for their choice. Parents who enroll their children in private schools believe that they are of better academic quality than public schools.

Teachers play a critical role in the success of the school as they can develop strategies that address the educational needs of every student and implement varied learning styles to convey the knowledge from the textbook to students successfully. Adeogun (2001) argued that the quality of the education system is dependent on the quality of its teachers and that a school with inadequate human resources may not be able to meet the objectives of the education system. Other scholars, exploring the role of teachers in more detail, argue that there are many ways in which teachers' attitudes, behaviour, and qualities can have a positive impact on student outcomes and school choice. For instance, Vanderbrook (2006) states that teachers must be motivated to teach very able students, employing creative and student-centered methods, without 
prejudice against either girls or boys or ethnic minorities. Teachers impact all aspects of the education process. Thus, it is important to investigate the performance of teachers in schools because they represent one of the most important reasons that may attract parents to value the school. It can be seen that teachers' qualifications; their knowledge of their academic subject; how they impart information to their children preferably using modern technologies, along with interesting, stimulating problem-solving methodologies are important to parents, and therefore influences their school choice. Equally, it is important to parents that the chosen school and its teachers have a sound reputation for addressing individual children's needs, build their selfconfidence and self-esteem, and ensure pupils' safety. Parents consider teachers to have a very considerable lifelong effect on pupils' personal and academic achievements. It is very important to parents who value teachers, therefore, that they use varied teaching methods, care for their children's well-being, help their children to overcome the challenges that face them in education by nurturing the whole child, i.e. his/her intellectual potential, respect for others, behaviour, physical development, self-awareness, encouraging good citizenship. This leads to the importance of teacher-children relationships. The relationship between students and teachers is very important in assisting students to overcome the educational challenges that they may face in their school lives, e.g. stress, self-esteem, difficulty in understanding some topics in a variety of lessons. Lee (2007) concluded that a positive relationship between teachers and students will motivate students' exploration and enthusiasm for knowledge, and thereby improves their educational attainment. He adds, therefore, "A trust relationship has been found to function as a motivational resource when students are faced with difficulties in school because trust relationships help adolescents develop positive psychological and emotional perceptions of them." In conclusion, the beneficial aspects embedded in solid teacher-student relationships are fundamental to school choice, especially when they nurture self-esteem, positive behavioural outcomes, and self-confidence and uphold the existing family standards of behaviour, making the school very attractive to parents.

The central point is that with reduced class size, students are given opportunities to practise interpersonal skills and to see themselves as significant individuals, with a sense of personal power, whose actions and opinions have ensured that each student perceives that he is known by important adults who care for him, thereby enhancing self-esteem. Having smaller classes is advantageous in many ways to both teachers and students because it makes the teaching/learning atmosphere more interesting and enjoyable; teachers have more time to become familiar with their student's abilities, interests and problems. This is indicative that small class size tends to positively impact the examination results of students. Small class size allows the teacher to support and help students individually by having the time and opportunity to answer each question or offer suggestions, while students are more involved in problem-solving activities. It is concluded that class size is a very important element in parental considerations when deciding which private or public school to choose. Parental decisions are based on the assumption that a smaller class equates to a more suitable quality learning environment in which the student's achievements and development will be enhanced through a constructive relationship 
between teachers and learners in which teachers have more time to devote to supporting each learner. Outstanding schools emphasize communication between parents and school as very important, parents as part of the success of the educational process. Thus, schools should plan to reduce the gap between the school and parents by making parents feel welcome, improving the relationship of trust between school and teachers and opening a discussion regarding morals and faiths. Collaboration between school and parents is necessary to achieve the school's educational objectives and to increase the awareness of parents of their role in educating children.

\section{CONCLUSION}

In terms of ranking the dominant factors in public and private school choice, class size came first. Parents generally made class size their top priority when considering which school to select for their children. Having smaller classes is advantageous in many ways to both teachers and students because it makes the teaching/learning atmosphere more interesting and enjoyable; teachers have more time to become familiar with their students' abilities, interests and problems.

The second most significant factor that this study revealed as a priority in parental choice is whether or not the school environment was favorable for the child in terms of his/her safety and well-being. Favorable environment is an extremely important factor in parents' decision making since parents perceive that ensuring a safe would not only allow their children to fulfill their potential but also contribute to solving some of the issues that a school may face. For example, fear of violence will lead to students' absence, poor performance, emotional withdrawal, depression, lowered self-esteem, along constant feelings of fear.

The third most important factor identified related to school choice in this study was the variety and quality of school facilities. The reasoning behind parental choice was that many participants considered it essential for their children to be exposed to modern technologies, stimulating teaching methods, and learning within a pleasant well-resourced environment to improve their performance within the classroom. Since schools pay more attention to facilities to develop students' skills, and in expanding the perceptions of students, this helps to make students more independent in terms of learning and more helpful in sharing their knowledge with their peers.

\section{REFERENCES}

Alansari, A. (2004). The reasons behind enrolment of children in private schools and views of parents about the private schools. Education Studies, 23, 2-17.

Aljaji, A. (2002). The perspectives of parents toward private schools in Saudi Arabia. Journal of Immam Mohammed bin Saudi University, 37. 563-597

Bhattarai, G. (2063 BS). Modernization, post modernization and changing prospect of education. Teacher Education, 6(1): 25-39.

Caddell, M. (2007). Private schools and political conflict in Nepal in P. Walford (ed.) 
Private Schooling in Less Economically Developed Countries: Asian and African Perspectives. Oxford: Symposium Books.

Coldren, J. and Boulton, P. (1991). Happiness as a criterion of parents' choice of school. Journal of Education Policy 6(2): 169-178.

Charles, G. W. (2011). Parental perceptions of school quality in public and private schools. Northcentral University.

Chitrakar, S. (2007). Challenges of educational development and its management in Nepal. Hepass journal, 6(1): 43-52.

Cohen, L., Manion, L., Morrison, K. \& Bell, R. (2011) Research methods in education, 7th edition. London: Routledge.

Denessena, E., Driessenaa, G., \& Sleegers, P. (2005). Segregation by choice? A study of group-specific reasons for school choice. Journal of Education Policy, 20, 347-368.

Hsu, Y., \& Yuan-fang, C. (2013). An analysis of factors affecting parents' choice of a junior high school. International Journal of Business, Humanities and Technology Vol. 3 No. 2. Taiwan

Khaniya, T.R. and Williams, J.H. (2004). Necessary but not sufficient: Challenges to (implicit) theories of educational change: Reform in Nepal's primary education system. International Journal of Educational Development 24(1): 315-328.

Kitaev, I. (1999). Private education in sub-Saharan Africa: A re-examination of theories and concepts related to its development and finance. Mechanisms and Strategies of Educational Finance. International Institute for Educational Planning/UNESCO, 7-9 rue Eugene-Delacroix, 75116 Paris, France. Retrieved from http://www.unesdoc.unesco.org/image/0011/0011763/17631e.pdf

Koirala. A. (2015). Debate on public and private schools in Nepal. Intj.Soc.Sei.Manoe. Vol-2 issue-1:3-8

Mathema, K.B. (2007). Crisis in education and future challenges for Nepal. European Bulletin of Himalayan Research 31: 46-66. Retrieved from http://himalaya.socanth.cam.ac.uk/collections/journals/ebhr/pdf/EBHR_31_04.pdf

Pokharel, T. (2008). An overview of community and private schools in Nepal. Hepass journal 7(1): 13-21.

Taylor, R. J. K. (1996). Variables motivating parents to choose a specific type of private school. Miami: Florida International University.

Tooley, J. (2001). The global education industry lesson from private education in developing countries. London: The institute of economic affairs. Retrieved from www.iea.org.uk/sites/default/files/publications/files/upld book48pdf.pdf

Woods, P., Bagley, C., \& Glatter, R. (1998). School responsiveness in a competitive climate: The public market in England. Educational Administration Quarterly, 34, 650-676. 